\section{The History and Future of Peru's Fast Growing Economy}

\author{
Alessandra Restifo \\ Sophomore, Political Science/Global Studies
}

\begin{abstract}
After the United States' withdrawal from the Trans-Pacific Partnership (TPP), the world of free trade entered a free-for-all, as countries searched for a viable course of direction toward a new free trade agreement. Peru seems to be leading an organized effort for the development of free trade agreements both within Latin America and across the Pacific. This is not surprising, as an analysis of Peru's economic history will demonstrate. Despite its social complications, free trade has usually led to prosperity for Peru. With it currently being one of Latin America's fastest growing economies, the loss of the TPP grants Peru the opportunity to see if their endurance and success will continue as they become more internationally integrated. If Peru succeeds with its plans of expanding free trade, which is analyzed in this paper, the country may serve as a model for countries just embarking to participate in the world of free trade economic policy.
\end{abstract}

\section{Introduction}

The Peruvian economy experienced a boom at the end of the $20^{\text {th }}$ century, which stimulated its remarkable economic growth throughout the $21^{\text {st }}$ century. Furthermore, Peru avoided the crash phenomenon, as well as a recession, often associated with economic booms. In addition to Peruvian economic policies, Peru's foreign investors and free trade agreements provided a strong base for its continued prosperity. However, the loss of the Trans-Pacific Partnership (TPP) provides both a threat to Peru's free trade-dependent economy and a chance for Peru to become a principal actor in a globalizing world economy. An analysis of Peru's economic development, the TPP itself and its relation to Peru, and Peru's "post-TPP" plans provides a substantial argument for Peru emerging as a pivotal member in the world of free trade.

\section{Development Since the $19^{\text {th }}$ Century}

At the turn of the $19^{\text {th }}$ century, a majority of the Peruvian population lived in the countryside, with Lima containing only 100,000 people in 1876 (Hudson \& Library of Congress Federal Research Division, 1993). Peruvians depended mostly on agriculture for their livelihood through subsistence farming and as their primary export. With foreign investment in Latin America on the rise during the dawn of the $20^{\text {th }}$ century, Peru developed an almost laissez-faire approach to its economy and set few restrictions on foreign investments and imports. Peru maintained this economic system through the Great Depression, while many other countries adopted protectionist policies.

During the end of the 1930s and World War II, protectionist policies allowed countries to stimulate their own economies and shape the new global economy that emerged as a result of World War II. While protectionist countries industrialized and prospered, Peru trailed behind. External economic pressure forced Peru to adopt extreme protectionist policies in the 1960s, which resulted in increased restrictions on foreign investment and more government interaction in the economy. However, these policies conflicted with the sharp population increase Peru experienced at 
the beginning of the $20^{\text {th }}$ century. The growth of employment in the manufacturing sector could not match the larger numbers of the growing population, especially with increased migration from rural areas to urban centers. This migration was caused by the decreasing ratio of arable land to the population that continued through the 1970s, severely damaging the agriculture industry. Resultantly, the manufacturing sector's share of the labor force fell from 13\% (1950) to 10\% (1990) and unemployment increased overall (Hudson \& Library of Congress Federal Research Division, 1993).

The few successes of Peru's economy during this period occurred because of an increasing focus on primary product exports. During the $19^{\text {th }}$ century, Peru's main exports were gold, silver, and guano. Guano, Europe's most important fertilizer at the time, made Peru the largest Latin American exporter to Europe (Hudson \& Library of Congress Federal Research Division, 1993). After the end of the guano boom, Peru's economy recovered using two methods: the development of new primary products and increased industrial production. The initial replacements were silver (33\% of export earnings [1890]), sugar (28\%), cotton, rubber, and wool (37\% collectively) (Hudson \& Library of Congress Federal Research Division, 1993). Copper and petroleum gained importance at the beginning of the $20^{\text {th }}$ century, as did fishmeal from anchovies in the post-World War II economy. Peru exported few manufactured goods - they accounted for $1 \%$ of Peru's total exports in 1960 (Hudson \& Library of Congress Federal Research Division, 1993) - until 1970. Both the aforementioned high rates of growth and overfishing, which destroyed Peru's successful fishmeal industry, shifted Peru towards the industrial sector and a return to foreign investment.

Prior to a shift back to foreign investment, Peru's first experiences with free trade would set a preconception for all future investments. In 1901, the increased value of Peruvian copper attracted United States (U.S.) firms, who bought almost all of the copper mines. Similarly, the International Petroleum Company (IPC) created a monopoly over oil production in Peru in 1914. Augusto B. Leguía y Salcedo's administration endorsed this foreign investment by enacting legislation that benefited foreign firms. In addition, Leguía y Salcedo's presidency had repressive overtones. This eternally linked foreign investment to the control of few at the expense of the public in Peru. Furthermore, history repeated itself with the dictatorial government legislating the Mining Code of 1950, which provided favorable tax provisions to investors that adversely affected Peruvian citizens through higher taxes and lower wages (Hudson \& Library of Congress Federal Research Division, 1993).

The Velasco government (1968-1975) provided an extreme alternative to the economic policies of these administrations. Beginning with the nationalization of IPC, the Peruvian government strictly limited foreign investment. Hostility toward foreign firms and a deteriorating economy caused foreign investors to withdraw. The Fujimori government (1990-2000), which is now classified as a dictatorship by political scholars, attempted to reverse Peru's economic doctrine beginning in 1990. The government disavowed all restricting economic policies and re-created a welcoming environment for foreign firms. However, little foreign investment entered the country initially because of the unstable state of 
the economy (Hudson \& Library of Congress Federal Research Division, 1993).

Nevertheless, Peru has become one of Latin America's fastest growing economies in the years since the Fujimori government. The dean of the Faculty of Economics at El Universidad del Pacifico states, "In the last 23 years, a social market economy has been consolidated and there is a consensus to maintain it as the axis of development enshrined in the 1993 Political Constitution" ("La Década", 2013). Therefore, Peru's success can be attributed to the core values of the economic system began by the Fujimori office: stability in prices and the exchange rate, pursuit of sustainable growth, defense of free trade, the attraction of foreign capital, and legal security of investments.

Recently, the following five countries were the largest investors in Peru: Spain (21.25\%), the United States (13.29\%), South Africa (7.67\%), Chile (7.25\%), and Brazil (5.89\%) (Swiss Chamber of Commerce in Peru, 2013). A majority of the foreign investment in Peru is directed toward its major sectors of manufacturing, construction, agriculture, and mining. However, one of the largest sectors of Peru's economy, trade, has contributed significant growth to Peru's economy. Peru has major free trade agreements (FTAs) with the U.S., Canada, China, Japan, and the European Union (EU) (Swiss Chamber of Commerce in Peru, 2013). Peru also has tight trade agreements with other Latin American countries. The most important, especially with regard to the Trans-Pacific Partnership, is the Pacific Alliance, which is a trade bloc, comprised of the countries of Peru, Chile, Colombia, and Mexico.

Evidently, business-friendly economic policies have fostered greater foreign investments into Peru, which have had extremely positive effects. For example, the poverty rate in Peru decreased from $52 \%$ at the turn of the century to $22.7 \%$ in 2014 (Editorial Board, 2016). Although the poverty rate is still high in Peru, it is comparatively much better than that in other Latin American countries. Other beneficial economic factors have formed Peru into a force of economic progress in Latin America. For example, the Central Reserve Bank predicts a GDP growth rate of $3.5 \%$ for 2017, the second highest in Latin America. Despite setbacks from the devastation of El Niño, the Central Reserve Bank projects Peru will recover in 2018 with a growth rate of $4.1 \%$ ("Peru 2017", 2017). An explicit example of Peru's success is its survival of the 2008 world recession. From 2009 to 2012, Peru's GDP experienced an average growth of $5.7 \%$, with the GDP experiencing an increase of $6.3 \%$ in 2012 (Swiss Chamber of Commerce in Peru, 2013). Peru's economic victory over the recession is a result of prior economic decisions. The 2000's commodity price boom largely benefited Peru's economy. The Peruvian government decided to save a majority of the money gained from the boom, and this allowed it to float while many other Latin American countries sank during the recession. Thus, Peru continued its economic growth on a fairly stable platform. For example, inflation is projected to drop to $2.4 \%$ in 2017, meaning Peru would have the second-lowest inflation rate in Latin America ("Peru 2017", 2017). This stability has continued the cycle of attracting more foreign investors (Gillespie, 2016).

Peru, in this time of relative prosperity, has developed economic goals for the future of its trade and investment. First of all, Peru hopes to form the aforementioned Pacific Alliance 
into a European Union of Latin America. The leaders of Colombia, Chile, Mexico, and Peru met in Santiago, Chile in 2017 to discuss combating global protectionism. The countries have begun developing plans to deepen financial ties across their countries, and eventually all of Latin America (De la Jara \& Iturrieta, 2017). The Pacific Alliance can be viewed as the first step of Peru's free trade plan. Professor Gonzalo Garland describes it as, "The declared intention of the country... to set up a logistics hub that integrates Latin America with Asia Pacific" ("La Década", 2013).

Peru's economic development has led the country to become one that is prepared for a more globalized world and increased free trade. The recent benefits of increased foreign investments show that Peru understands the system and how it will benefit. The shift from primary product exports to industrialization and the relatively quick recovery from the 2008 recession demonstrate the adaptability of Peru's economy. The largest source of evidence of Peru's positive relation with free trade is the 2016 election of the current president, Pedro Pablo Kuczynski, a Polish neoliberal who has strong beliefs in foreign investment and increasing exports. However, the citizens of Peru still have concerns. The association of repressive governments with free trade is still imprinted on the average Peruvian's mind. These two mindsets clashed again with the introduction of the TPP.

\section{Trans-Pacific Partnership}

The Trans-Pacific Partnership was a regional trade agreement among twelve nations that border the Pacific Ocean: U.S., Peru, Australia, Brunei, Canada, Chile, Japan, Malaysia, Mexico, New Zealand, Singapore, and Vietnam. If ratified, this agreement would have been the largest regional trade agreement in history, with the participating countries composing an annual GDP of \$28 million and $40 \%$ of the global GDP (Granville, 2017). Furthermore, its broad language would allow for the introduction of more Asian countries. The TPP had five goals that the members wished to address: eliminating remaining tariffs; standardizing rigorous environmental, labor, and intellectual property standards; allowing free transfer of data across borders; increasing opportunities for service industries; and addressing partiality toward state-owned businesses. While a subvert goal of the U.S. was to pivot economic power away from China through the TPP, the ultimate purpose of the TPP was to create a Pacific free-trade zone.

Peru, as mentioned before, was divided on the TPP. At the Asian-Pacific Economic Cooperation (APEC) 2016, President Pablo Kuczynski stated, "In recent years, we have seen how companies go bankrupt and how people are left jobless due to falling trade... World trade has to grow and protectionism has to be defeated" (Villalobos, 2016). The Peruvian government's current neoliberal economic policy agrees strongly with the TPP and many government officials supported its development. Alternatively, Peruvian citizens focused on the potential dangers of the TPP, holding many protests prior to the U.S.'s withdrawal. The main arguments were against policies that limited Peruvian sovereignty and pharmaceutical policies. Opponents of the TPP saw it as a threat to environmental issues, health care, Peruvian culture, and freedom on the Internet. In addition, trade provisions within the TPP enforced the use of genetically modified seeds and weakened workers' and farmers' rights. The TPP could have granted pharmaceutical 
companies monopolies over certain medicines, resulting in higher prices that many Peruvians cannot afford (Mora, 2016).

Both views were expressed in the revised TPP. First of all, Peru only had to enforce the partnership's protections on medicines for five years during the decade following the ratification instead of eight years. Furthermore, the TPP would have eliminated 18,000 international trade taxes, but Peru was granted grace periods to phase out tariffs and total exemption of tax elimination in the following industries: some food and agriculture; clothing and textiles; light industrial product; and the entertainment industry (Post, 2015). The entertainment industry was included in various efforts to preserve Peru's cultural heritage in light of the TPP extending bidding on government contracts to foreign companies. These efforts included enforcing minimum requirements for Peruvian staff in media production and broadcast, preserving the right to pass laws that would protect indigenous cultures and Peruvian cultural staples, and defining the nationality of ownership if selling a state firm. The following industries were completely exempt from the bidding: clothing for the military, bedding for the El Salud healthcare system, accounting and arbitration services, food assistance programs, alpaca fibers, financial services, and products for Peru's embassies abroad. These sectors were considered to be essential to the Peruvian government and people, and critically important to the point where international intervention would not be welcomed (Post, 2015).

The TPP, in terms of Peru, took into account basic principles of free trade. Also, the concerns of the Peruvians were addressed within the document, mainly the passages about medicine protection and the preservation of cultural heritage. The Peruvian government would have triumphed, as they expected to export $\$ 2.25$ billion in products and services to the five countries (i.e. Australia, New Zealand, Vietnam, Malaysia, and Brunei) of the TPP with whom Peru does not have FTAs (Post, 2015). Nevertheless, the international concern over pharmaceutical companies, even with a reduced term of protection, is legitimate especially when many Peruvians would not be able to afford more expensive medicines. Other international concerns affect people of all socio-economic levels. For example, labor groups in developed countries are worried about jobs being exported to less-developed countries, while less-developed countries will have to abide by potentially nonviable international labor laws. Farmers in all of the TPP countries, especially food exporting countries (e.g. New Zealand, Australia) would have benefited largely from cuts in tariffs.

Overall, the decreased tariffs and increased competition that would result from the legislation in the TPP would have benefited the countries on a macro level, but leave small farmers and small businesses in uncertainty (Naidu-Ghelani, 2015).

However, the U.S. withdrew from the TPP in January 2017 and the eleven remaining countries have been forced to form alternative plans for an FTA. Peru has already moved into action and has received strong support. Peru found a natural conclusion in a pivot towards Asia, mainly China. Peru, with Latin America's fastest growing economy, has played a pivotal role in the struggle between the U.S. and China for control over Latin America. Over the last decade, Chinese companies have invested $\$ 18$ million in infrastructure and mining in Peru as an attempt to lessen U.S. influence (Gillespie, 
2016). When viewing Peru's economic policy through this lens, Peru's reasons for joining the TPP are as much about free trade as it is about increasing economic ties with Asia. As the future of the TPP grows dimmer, Peru has begun to strengthen its ties with Asian economies. While Peru and China already have a bilateral free trade deal, they have recently met to discuss updating its terms (Taj, 2016). Peru and its fellow members of the Pacific Alliance are strengthening their economies in order to create more FTAs with the Association of Southeast Asian Nations (ASEAN). Garland's earlier assertion of Peruvian trade policy appears in the joint effort of the Pacific Alliance to improve their economies and their plans to enter into these FTAs as a trade bloc ("Peru 'Prefers", 2017).

\section{Conclusion}

Free trade has produced amazing results for Peru macroeconomically. Peru has developed into one of the largest growing and most stable economies in Latin America, which placed the country in a crucial position in both the U.S. - China economic conflict and the production of the Trans-Pacific Partnership. In the "post-TPP" economic world, Peru has risen as a leader of FTA formation (i.e. the Pacific Alliance, FTAs with Asia). Outside of macroeconomics, the Peruvian people still maintain their suspicions about FTAs and foreign investments. Therefore, it can be concluded that Peru's government is prepared to enter into a primary role in the globalized economy despite the resistance of the Peruvian people. As seen with Western countries in post-WWII economic development, countries that are principal actors in a changing global economy often benefit the most from it because they shape the economic sphere and increase their socio-economic influence. Peru now has that opportunity as they lead Latin America in an increasingly global free-trade economy. Furthermore, its recent actions display a willingness to assume a leading position in the advancement and expansion of free trade. To ensure the participation of the Peruvian public, the government must listen to the concerns of the people, avoiding the authoritarianism of previous pro-free trade administrations as it moves forward in economic globalization.

\section{References}

Central Intelligence Agency. (2017, January 12). Peru [Fact sheet]. Retrieved March 27, 2017, from cia.gov website: https://www.cia.gov/library/publications/t he-world-factbook/geos/pe.html

De la Jara, A., \& Iturrieta, F. (2017, March 10). Pacific Alliance trade bloc seeks to deepen financial ties. Reuters. Retrieved from

http://www.reuters.com/article/us-trade-al ianza-idUSKBN16H2JO

Editorial Board. (2016, June 12). Peru's rise. The Washington Post. Retrieved from https://www.washingtonpost.com/opinion s/perus-rise/2016/06/12/6d7dd322-2f30-1 1e6-b5db-e9bc84a2c8e4 story.html?utm term $=.3 \mathrm{e} 9 \mathrm{~d} 6 \mathrm{~b} 2 \mathrm{~b} 05 \mathrm{~d} 1$

Gillespie, P. (2016, November 17). Peru is shining amid Latin America woes. Retrieved March 27, 2017, from money.cnn.com website: http://money.cnn.com/2016/11/17/news/e conomy/peru-latin-america-apec/ 
Granville, K. (2017, January 23). What is TPP? Behind the trade deal that died. The New York Times. Retrieved from https://www.nytimes.com/interactive/201 6/business/tpp-explained-what-is-trans-pa cific-partnership.html? $\mathrm{r}=0$

Hudson, R. A., \& Library of Congress Federal Research Division. (1993). History of the economy. In Peru: A country study.

Retrieved from

https://www.loc.gov/item/93019676/

La década prodigiosa: Perú disfruta del mejor momento económico de su historia [The prodigious decade: Peru enjoys the best economic moment in its history]. (2013, June 23). La Republica. Retrieved from http://larepublica.pe/23-06-2013/la-decad a-prodigiosa-peru-disfruta-del-mejor-mo mento-economico-de-su-historia

Mora, R. (2016, April 18). Peru: Activists prepare sixth march against the TPP. Retrieved March 27, 2017, from telesurtv.net website:

http://www.telesurtv.net/english/news/Per u-Activists-Prepare-4th-March-Against-th e-TPP-20160418-0036.html

Naidu-Ghelani, R. (2015, October 6). TPP trade deal: Who are the winners and losers? Retrieved March 27, 2017, from bbc.com website: http://www.bbc.com/news/business-3445 $\underline{1423}$

Peru 2017 GDP to be one of LatAm Highest at 3.5\%. (2017, March 25). Andina.

Retrieved from http://www.andina.com.pe/Ingles/noticia- peru-2017-gdp-to-be-one-of-latam-highes t-at-35-659862.aspx

Peru "prefers" FTA with Asia through Pacific Alliance. (2017, March 10). Latin American Herald Tribune. Retrieved from

http://www.laht.com/article.asp?ArticleId $=2432649 \&$ CategoryId $=14095$

Post, C. (2015, November 12). What did Peru get out of the Trans-Pacific Partnership? Retrieved March 27, 2017, from perureports.com website: http://perureports.com/2015/11/12/what-d id-peru-get-out-of-the-trans-pacific-partne rship/

Swiss Chamber of Commerce in Peru. (2013, June). Peru major business sectors. Switzerland Global Enterprise, 1-5.

Retrieved from http://www.s-ge.com/sites/default/files/pr ivate files/WZ 1307 E Wirtschaftszwei ge-Peru 3.pdf

Taj, M. (2016, November 22). Peru proposes talks to save TPP after Trump firms up opposition. Reuters. Retrieved from http://www.reuters.com/article/us-peru-tp p-idUSKBN13H2CC?il=0

Villalobos, M. R. (2016, November 18). PPK: "El protecctionismo tiene que ser deterrotado" [PPK: Protectionism has to be defeated]. El Comercio. Retrieved from http://elcomercio.pe/apec/noticias/ppk-pr oteccionismo-tiene-que-derrotado-noticia1947509 
